\title{
Elevation and volume changes on the Harding Icefield, Alaska
}

\author{
G. AĐalgeirsdóttir, ${ }^{*}$ K. A. Echelmeyer, W. D. Harrison \\ Geophysical Institute, University of Alaska Fairbanks, Fairbanks, Alaska 99775-7320, U.S.A.
}

\begin{abstract}
Airborne surface elevation profiles of the Harding Icefield, southcentral Alaska, were made in 1994 and 1996. Thirteen glaciers were profiled, along with the upper region of the icefield. The profiles were compared to U.S. Geological Survey topographic maps made in the 1950s, to obtain elevation and volume changes. Comparison of the changes for the different glaciers shows no significant correlation between volume change and the type of glacier or characteristics such as location, aspect, size, slope or terminus changes. Estimated total volume change for this $\sim 43$ year period is about $-34 \mathrm{~km}^{3}$, which corresponds to an area-average elevation change of $-21 \mathrm{~m}$. The estimated error in this elevation change of $5 \mathrm{~m}$ is mainly due to errors in the maps at higher elevations. Our measurements provide an accurate baseline against which future determinations of volume change can be made.
\end{abstract}

\section{INTRODUCTION}

Small valley glaciers are believed to be sensitive indicators of climatic change, and many attempts have been made to establish the relation between glacier extent, volume and climate (e.g. Jóhannesson and others, 1989; Oerlemans, 1994). Mountain glaciers and small ice caps are also believed to account for between one-third and one-half of observed rise in sea level, with the largest contribution from glaciers in the coastal mountains bordering the Gulf of Alaska (Meier, 1984, 1990; Dyurgerov and Meier, 1997). However, these analyses were based on very limited datasets, which, in many cases, entailed the assumption that the mass-balance record of one glacier is representative for a large region. Tests of this assumption are limited (Rabus and Echelmeyer, in press), and it remains of interest to determine how glaciers of different geometries and types (tidewater vs land-terminating) in one region respond to a similar climate change.

A new method has recently been developed for measuring profiles of mountain glaciers relatively quickly and accurately, that of airborne surface-elevation profiling (Echelmeyer and others, 1996; Sapiano and others, 1998). As part of these studies, we profiled the upper region of the Harding Icefield, Alaska, and 13 outlet glaciers emanating from the icefield. Six of the outlet glaciers were profiled in 1994, seven in 1996 and three in both 1994 and 1996. The profiles were compared to the U.S. Geological Survey (USGS) 1:63360 topographic maps constructed from aerial photographs taken in 1950-52. Here we present their elevation and volume changes over this time interval. The changes of different types of glaciers, tidewater on the east side of the icefield and land-terminating glaciers on the west, all of which drain the same ice cap, are compared to reveal

\footnotetext{
* Versuchsanstalt für Wasserbau, Hydrologie und Glaziologie, ETH-Zentrum, CH-8092 Zürich, Switzerland
}

differences in their response to the same large-scale climatic change. From the repeated profiles we are able to calculate the short-term elevation changes for three glaciers and the upper area of the icefield from 1994 to 1996. We also present terminus and volume changes for each glacier, as well as an estimated total volume change for the entire icefield. The repeatability of the profiling system and the quality of the maps are also discussed.

\section{THE HARDING ICEFIELD}

The Harding Icefield is located on the Kenai Peninsula in south-central Alaska (Fig. 1). It is the largest icefield completely contained within the boundaries of the United States. The icefield is about $80 \mathrm{~km}$ long (northeast-southwest) and $50 \mathrm{~km}$ across. Including the outlet glaciers, it covers an area of about $1800 \mathrm{~km}^{2}$. Slightly more than half of the icefield lies within the present boundary of Kenai Fjords National Park; the remainder lies within the Kenai National Wildlife Refuge. At least 38 glaciers of different sizes and types flow from the Harding Icefield. Seven of them are presently tidewater glaciers.

Present climate may be described as sub-Arctic maritime along the south and east sides of the Kenai Mountains, and sub-Arctic continental on the northwest. The east side is open to the ocean and receives copious precipitation in the form of maritime snow (Benson, 1980). This precipitation decreases towards the west, as can be seen in the long-term average annual precipitation records: Seward, on the east, receives $1.7 \mathrm{~m}$, while Homer and Kenai, to the west, receive only 0.6 and $0.5 \mathrm{~m}$, respectively. These latter two stations are in the precipitation shadow of the Kenai Mountains (S. Bowling, ftp://climategi.alaska.edu/public/Monthly.P). The icefield receives substantially more precipitation than Seward. For example, during one storm almost three times as much precipitation fell at 1275 ma.s.l. on the Harding Icefield as in Seward (Rice, 1987). 

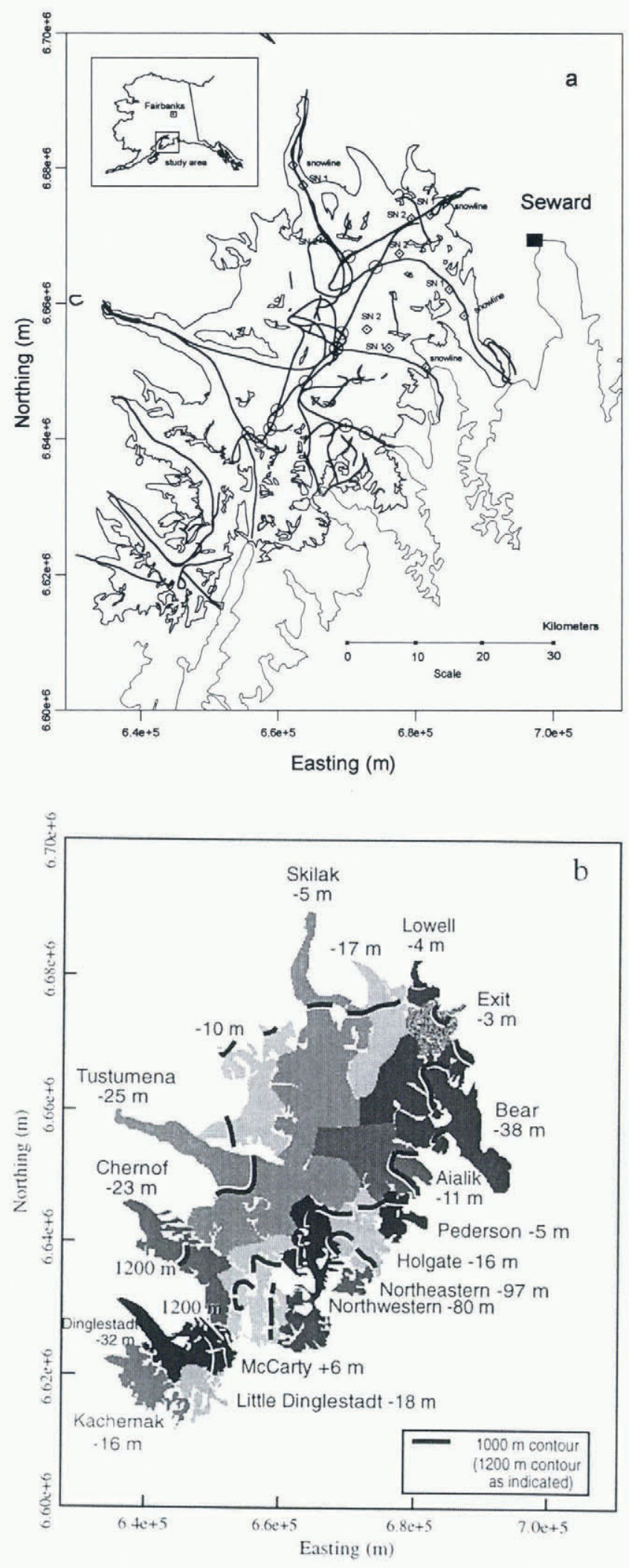

Fig. 1. (a) Harding Icefield, showing the profiles flown in 1994 and 1996. Coordinates are in UTM, zone 5. The circles are the icefield crossing points between 1996 and 1994 profiles, and the diamonds are locations of snow-depth measurements and the snowline as measured in May 1996. (b) Boundaries of the different glaciers on the Harding Icefield. The $1000 \mathrm{~m}$ contour on the main icefield and the $1200 \mathrm{~m}$ contour on the south icefield are shown as solid black lines. The numbers below the glacier names are area-averaged elevation changes.

The equilibrium-line altitude (ELA) of the Harding Icefield was estimated by Meier and Post (1962) to be around $600 \mathrm{~m}$, and the accumulation area ratio (AAR) to be 0.68 .
The more recent tidewater glacier study of Viens (1995) indicated a higher ELA of about 930-1190 m on Northwestern and McCarty, and $610-730 \mathrm{~m}$ on Holgate and Aialik Glaciers, respectively. Each of these glaciers has a significant part of its accumulation area well above the stated ELAs. This indicates that Harding Icefield is relatively insensitive to small climate changes (Bodvarsson, 1955).

Late-Holocene glacier fluctuations, glacial chronologies and the vegetation chronosequence in the Kenai Fjords have been studied by Post (1980a, b, c), Wiles and Calkin (1990, 1994), Helm and Allen (1995) and Wiles and others (1995). Rice (1987) compared photographs of the icefield to USGS maps based on 1950-51 acrial photography and found that the areal extent of the icefield decreased by about $5 \%$ over a period of 34 years. Greatest loss was near sea level along the Gulf of Alaska and at 300-600 m elevation along the north and west sides of the icefield. Also, many small glaciers below $1000 \mathrm{~m}$ disappeared.

The characteristics of the 13 glaciers that we investigated are given in Table 1. Figure 1 shows the outline of the icefield and the boundaries that we defined for the glaciers, the ground tracks of the profiles, snow-depth measurement sites and crossing-point locations.

\section{THE PROFILE DATA}

The airborne profiling system uses dual-frequency kinematic global positioning system (GPS) methods to determine the absolute position of the aircraft, an infrared laser ranger to measure the distance from the aircraft to the point on the surface, and a vertical-axis gyro to measure the orientation of the laser beam. Post-processing of the data gives the ground track of the profile and the absolute elevation of the surface at points spaced approximately $1.5 \mathrm{~m}$ along that track. The nominal accuracy of the system is $0.3 \mathrm{~m}$ (Echelmeyer and others, 1996).

\section{GPS data quality}

The quality of kinematic GPS data depends on the number and geometry of the observed satellites. All the profiles obtained in 1994 had very good GPS solutions because $6-8$ satellites were observed during the flights, with good satellite geometry. In 1996 poor weather conditions made it difficult to fly during times of optimal satellite configuration, and often only 4-5 satellites were observed. This caused the data for several 1996 flights to be of poorer quality (Adalgeirsdóttir, 1997). However, as shown by the crossing-point analysis following, the vertical accuracy of the 1996 data is still within about $0.35 \mathrm{~m}$. During good conditions the accuracy is $0.20 \mathrm{~m}$. These accuracies are better than the vertical accuracy of the maps, which is $15 \mathrm{~m}$ at best.

\section{Crossing points}

The repeatability of the system has been closely examined by analysis of crossing points. Where one profile crosses another, the elevations of the points from the two profiles that are closest to each other can be compared. An alternative method is to compare the elevations of all points that are within $1 \mathrm{~m}$ of each other from the two profiles. The latter method gives a statistically more robust dataset. We have applied both methods, with the results presented in Table 2. The data in this table are divided into two groups depending on whether the aircraft landed between measurements 


\begin{tabular}{|c|c|c|c|c|c|c|c|c|}
\hline \multirow[t]{2}{*}{ Glacier } & $\begin{array}{l}\text { Location on } \\
\text { icefield }\end{array}$ & Aspect & Type ${ }^{\mathrm{I}}$ & $\begin{array}{c}\text { Elevation } \\
\text { interval }\end{array}$ & Length & Slope $^{2}$ & Date of profile & Date of map photography ${ }^{2}$ \\
\hline & & & & $\mathrm{m}$ & $\mathrm{km}$ & 9 & & \\
\hline
\end{tabular}

\begin{tabular}{|c|c|c|c|c|c|c|c|c|}
\hline Aialik & $\mathrm{E}$ & E & TW & $0-1400$ & 11 & 11 & 29 May 1994 & $\begin{array}{l}\text { u: } 2 \text { August } 1950 \text { or } 25 \text { June } 1951 \\
\text { 1: } 8 \text { August } 1950\end{array}$ \\
\hline Bear & $\mathrm{E}$ & $\mathrm{SE}$ & TW/LK & $0-1200$ & 26 & $\begin{array}{l}\mathrm{u}: 4 \\
\mathrm{l}: 2\end{array}$ & 28 May 1994 & $\begin{array}{l}\text { u: } 25 \text { June } 1951 \text { and } 8 \text { August } 1950 \\
\text { l: } 2 \text { August } 1950\end{array}$ \\
\hline Exit & $\mathrm{N}$ & $\mathrm{NE}$ & $\mathrm{L}$ & $150-1200$ & 7 & 10 & $\begin{array}{l}28 \text { May } 1994 \\
30 \text { May } 1996\end{array}$ & 25 June 1951 and 8 August 1950 \\
\hline Holgate & $\mathrm{E}$ & $\mathrm{E}$ & TW & $0-1300$ & 8.5 & 7 & $\begin{array}{l}29 \text { May } 1994 \\
19 \text { May } 1996\end{array}$ & 2 and 8 August 1950 \\
\hline Skilak & $\mathrm{N}$ & $\mathrm{N}$ & $\mathrm{L} / \mathrm{LK}$ & $150-1400$ & 26 & $\begin{array}{l}\mathrm{u}: 3 \\
\mathrm{l}: 6\end{array}$ & $\begin{array}{l}29 \text { May } 1994 \\
29 \text { May } 1996\end{array}$ & $\begin{array}{l}\text { u: } 25 \text { June } 1951 \text { and } 7 \text { August } 1950 \\
\text { l: } 7 \text { August } 1950\end{array}$ \\
\hline Tustumena & W & W & $\mathrm{L} / \mathrm{LK}$ & $90-1400$ & 35 & 2 & 29 May 1994 & $\begin{array}{l}\text { u: } 2 \text { and } 9 \text { August } 1950 \text { or } 25 \text { June } 1951 \\
\text { l: } 25 \text { June } 1951\end{array}$ \\
\hline Chernof & W & NW & $\mathrm{L}$ & $370-1700$ & 24 & 4 & 20 May 1996 & $\begin{array}{l}\text { u: } 2 \text { and } 9 \text { August } 1950 \\
\text { 1: } 9 \text { August } 1950 \text { or } 25 \text { June } 1951\end{array}$ \\
\hline Dinglestadt & SW & NW & LK & $230-1100$ & 15.5 & 3 & 19 May 1996 & $\begin{array}{l}\text { u: } 15 \text { August } 1952 \\
\text { l: } 9 \text { August } 1950\end{array}$ \\
\hline Kachemak & SW & W & $\mathrm{L}$ & $460-1200$ & 8 & $\begin{array}{l}\mathrm{u}: 3 \\
\mathrm{l}: 7\end{array}$ & 19 May 1996 & 15 August 1952 \\
\hline $\begin{array}{l}\text { Little } \\
\text { Dinglestadt }\end{array}$ & S & $\mathrm{E}$ & $\mathrm{TW} / \mathrm{L}$ & $0-1000$ & 7 & 10 & 19 May 1996 & 15 August 1952 \\
\hline McCarty & $\mathrm{s}$ & $\mathrm{s}$ & TW & $0-1200$ & 13 & $\begin{array}{l}\mathrm{u}: 8 \\
\mathrm{l}: 3\end{array}$ & 20 May 1996 & 9 August 1950 \\
\hline Northeastern & $\mathrm{SE}$ & SW & $\mathrm{TW} / \mathrm{L}$ & $0-1000$ & 6 & $\begin{array}{l}\text { u: } 24 \\
\text { l: } 8\end{array}$ & 19 May 1996 & 2 August 1950 \\
\hline Northwestern & SE & S & TW & $0-1200$ & 15 & $\begin{array}{l}\mathrm{u}: 2 \\
\mathrm{l}: 11\end{array}$ & 19 Мау 1996 & 9 August 1950 \\
\hline
\end{tabular}

Type of glaciers: L, land-terminating; TW, tidewater; LK, lake-terminating; / indicates a change in type caused by retreat.

${ }^{2}$ Some glaciers were divided into upper region $(\mathrm{u})$ and lower region $(\mathrm{l})$ if there was a difference between the two.

Table 2. Crossing-point statistics representing the repeatability of the system

Number Points Mean rms ${ }^{1}$ Weighted Error of
of cross- $<1 m$ elevation
ings horizon- diff.
tal dif-
ference

$\mathrm{m} \quad \mathrm{m}$

\begin{tabular}{|c|c|c|c|c|c|c|}
\hline 1994 , all data & 26 & 83 & -0.17 & 0.46 & & \\
\hline 1996 , all data & 11 & 58 & 0.34 & 0.42 & & \\
\hline \multicolumn{7}{|c|}{ Crossings points during the same flight: } \\
\hline 1994 & 21 & 75 & -0.19 & 0.49 & & \\
\hline 1996 & 6 & 19 & 0.20 & 0.28 & & \\
\hline \multicolumn{7}{|l|}{ Crossing points in different flights: } \\
\hline 1994 & 5 & 8 & 0.06 & 0.18 & & \\
\hline 1996 & 5 & 39 & 0.42 & 0.48 & & \\
\hline \multicolumn{7}{|c|}{ Closest point analysis for the 1994 data: } \\
\hline Crossings on outlet glaciers & 19 & & 0.15 & 0.66 & 0.10 & 0.05 \\
\hline Crossings on the icefield & 10 & & 0.24 & 0.34 & 0.07 & 0.04 \\
\hline $\begin{array}{l}\text { Crossings between } \\
\text { different flights }\end{array}$ & 5 & & 0.13 & 0.19 & 0.05 & 0.08 \\
\hline \multicolumn{7}{|c|}{ Closest point analysis for the 1996 data: } \\
\hline Crossings on icefield & 6 & & 0.00 & 0.34 & 0.13 & 0.04 \\
\hline $\begin{array}{l}\text { Crossings between } \\
\text { different flights }\end{array}$ & 7 & & 0.38 & 0.49 & 0.21 & 0.08 \\
\hline
\end{tabular}

${ }^{1}$ Root-mean-square elevation difference. (different flights) or not. If the crossing was from different flights, the second profile was usually measured within 24 hours of the first one. Also shown are the weighted mean differences. In the latter case, each crossing was weighted by a factor equal to one over the combination of two independent errors: the horizontal distance between the two points, transformed to a vertical difference using the local surface slope, and the estimated error in elevation as determined by the height above the surface and the tilt of the beam relative to the normal of the glacier surface. Points from the same flight in 1994 are divided into those from outlet glaciers and those from the upper icefield.

Comparison of all the points that are less than $1 \mathrm{~m}$ apart horizontally, without weighting, shows that the mean elevation difference was $-0.17 \mathrm{~m}$ in 1994 and $0.34 \mathrm{~m}$ in 1996. The difference between 1994 and 1996 can be explained, in part, by the difference in the quality of the GPS data for the two years, as stated above. The crossing points in the same flight had a mean difference of -0.19 and $0.20 \mathrm{~m}$ for 1994 and 1996, respectively. When landing between measurements, the difference for the 1994 data was small, while in 1996 the mean difference for different flights was $0.42 \mathrm{~m}$.

When only the closest points between the two passes are examined and they are weighted by the two errors, all mean differences are $0.21 \mathrm{~m}$ or less. Thus, under good satellite conditions (number and geometry), we believe that the system is capable of repeating a measurement to within about $0.20 \mathrm{~m}$ on moderately sloped terrain, while under poor conditions the accuracy is somewhat less. 


\section{SNOW DEPTHS AND SEASONAL GORRECTIONS}

The comparison of our elevation data with those from the topographic maps is further complicated because the two datasets were collected at different times of the year. To correct for this difference, several snow depths were measured in 1996 (Fig. 1 and Table 3). Where the snow was not measured, we extrapolated using the altitudinal gradients defined by the Aialik data for tidewater glaciers and the Skilak data for land-terminating glaciers.

Table 3. Snow depths measured in May 1996. See Figure 1 for location of measurement points (SN1 and SN2)

\begin{tabular}{lcc}
\hline Glacier & S.N1 & SN2 \\
& $\mathrm{m}$ & $\mathrm{m}$ \\
\hline Skilak & 1.1 & 3.4 \\
Exit & 3.3 & 3.7 \\
Bear & 1.5 & 5 \\
Aialik & 4.8 & $>4.6$ \\
\hline
\end{tabular}

Another complication arises because the photos that were used to make the maps were themselves taken at different times of the year. Some glaciers were photographed in June and others in August, so the snow-depth correction needed to be adjusted for different glaciers, as discussed by Adalgeirsdóttir (1997). We subtracted an appropriate amount of the measured snow thickness from the profile data to correct it to the date of the map photographs (June or August), assuming a linear decrease to zero in snow depth over the melt season (no ablation measurements were made). The photography dates for each glacier are listed in Table 1; the time interval for our thickness changes can be obtained by subtracting the year of the photos from the profile year.

\section{COMPARISON WITH THE MAPS}

The profile data are given with respect to different horizontal and vertical datums than the USGS maps. The profile coordinates are obtained in the World Geodetic System of 1984 (WGS84) and height above ellipsoid, and we transformed these to the map datums (North American Datum 1927 (NAD27) and National Geodetic Vertical Datum of 1929 (NGVD29), elevations relative to mean sea level (MSL)) (Echelmeyer and others, 1996). The U.S. National Geodetic Survey model GEOID94 (Alaska) was used to transform the vertical coordinates. All horizontal coordinates were projected to Northing and Easting of the planar Universal Transverse Mercator system (UTM). The zone boundary between UTM zones 5 and 6 bisects the Harding Icefield, so the data were transformed to either zone as required.

The elevation difference between the maps and the profiles was obtained by first digitizing the glacier contours on the maps. Then the closest point where a profile crosses a contour was selected and the elevation difference between the profile at that point and the contour was determined. Software developed by B. Rabus, J. Sapiano, J. Gorda and L. Sombardier (personal communication, 1994-96) was used for this purpose.
As described in a later section, an additional estimate of volume change was made by comparing the profiles to the Alaska digital elevation model (DEM), which is given in the World Geodetic System 1972 (WGS72) and NGVD29. For this comparison we used horizontal profile coordinates in WGS84 because they are sufficiently close to those in WGS72 (about $3 \mathrm{~m}$ in Northing and $7 \mathrm{~m}$ in Easting on the Harding Icefield).

\section{Map quality}

The USGS maps have a contour interval of $100 \mathrm{ft}(30.5 \mathrm{~m})$. Their stated accuracy is half a contour interval in the vertical and about $50 \mathrm{~m}$ in the horizontal, both of which are almost two orders of magnitude less precise than the profile data. We have found that this map accuracy can vary from region to region on a given map, depending upon the quality of the aerial photographs used in the map construction, the quality of the ground control, the steepness of the terrain and other factors. To evaluate the map quality for each glacier, we obtained most of the photographs used to construct the maps, along with the cartographers' reports for each map and an index map showing the coverage of each photograph (USGS, Rocky Mountain Mapping Center). From the index map we found that some areas were covered by more than one flight-line, flown in different years and at a different time of the year. Also, the cartographer did not always record which photos were actually used to make the map. In most of the ambiguous cases, we examined the photos and were able to identify those that were actually used by comparing the areal extent of nunataks and bedrock in the photos and on the maps. However, this was not always possible. For example, in the accumulation area above Exit, Bear and Skilak glaciers, we found that photos from different dates were used in the mapping. The contours in these areas were mismatched because of real changes that occurred between the different photo dates, and these contours were smoothed by the cartographer. The dates listed in Table 1 are our best estimates for the actual mapping photographs used for each glacier.

On the higher areas of the icefield, where the surface is relatively flat, it is often difficult to see any contrast in the photos. This lack of definition made it unfeasible to map some of the snow-covered areas stereoscopically, and the cartographer stated that contours in these regions were simp!y "sketched" (USGS Quadrangle reports for Seward A-8 and Kenai A-1, and personal communication fromJ. Sadlik, 1996). In those areas with poor contrast the elevation changes from the maps to the different profiles lacked consistency. In the upper regions of Skilak, Exit and Aialik glaciers there is a considerable difference between the shape of the profiled and mapped surfaces. We found that this lack of surface definition in the photographs was characteristic of the areas above the snowline and crevassed areas. Using the mapping photographs, we estimated the maximum elevation for good surface definition to be about $1000 \mathrm{~m}$ for the main icefield and $1200 \mathrm{~m}$ for the southern part. We then calculated the scatter in the elevation changes above these elevations. The mean change from the profiles to the maps was $0.1 \mathrm{~m}$, with a standard deviation of $45.5 \mathrm{~m}$. This large scatter is an indication of the poorly defined contours, and we assume that the standard deviation is an indicator of the random error in the contours in this upper region. Because a large fraction $(0.70)$ of the total icefield area is above 1000 
or $1200 \mathrm{~m}$ (Fig. 1b), the volume-change calculation is strongly affected by the errors there.

\section{Proglacial bedrock points and nunataks}

Profile elevations were compared to mapped bedrock contours in proglacial areas and to nunataks within the icefield boundaries in order to obtain another estimate of map accuracy, assuming that the bedrock has not changed. The profiles crossed 19 bedrock contours in front of a total of six glaciers. The results of this comparison are shown in Table 4, where the mean difference is the apparent elevation change averaged over all the points where the profiles cross bedrock contours. The standard deviation about this mean (often called the standard deviation) indicates the typical scatter, and, as such, it is a measure of the random error in the contours. The standard deviation of the mean (often called the standard error) shows that the mean difference is not significantly different from zero. Thus, based on this analysis, no systematic errors in the maps are indicated, and the random errors are about $12 \mathrm{~m}$ or less in these proglacial regions, consistent with the published accuracy.

\section{Table 4. Profile minus mapelevation in proglacial regions and on nunataks within the icefield}

\begin{tabular}{lcccc}
\hline & $\begin{array}{c}\text { Number of } \\
\text { crossings }\end{array}$ & $\begin{array}{c}\text { Mean differ- Std dev. about Std dev. of the } \\
\text { ence } \\
\text { the mean }\end{array}$ & mean \\
& & $\mathrm{m}$ & $\mathrm{m}$ & $\mathrm{m}$ \\
\hline $\begin{array}{l}\text { Proclacial bedrock } \\
\text { Nunatak points (1996) }\end{array}$ & 19 & 1.4 & 12.2 & 2.8 \\
& 54 & -3.4 & 24.0 & 3.2 \\
\hline
\end{tabular}

Fifteen nunataks were profiled in 1996. The results were similar to those in the proglacial areas, in that no systematic error in the maps was apparent. However, the larger scatter indicates that the random error in these nunatak contours is about $24 \mathrm{~m}$. This may be a consequence of steeper slopes on the nunataks, which would cause horizontal positioning errors on the maps to translate into larger vertical errors.

As a result of the 1964 earthquake (magnitude: $M_{\mathrm{w}}=9.2$ ), bedrock elevations around the icefield have not been strictly constant, as we assumed. There was coseismic subsidence of about $1 \mathrm{~m}$ in the Kenai Mountains (Holdahl and Sauber, 1994), followed by post-seismic rebound of about $0.2-0.6 \mathrm{~m}$ (Cohen and Freymueller, 1997). However, these tectonic elevation changes are too small to be resolved from the map comparisons.

\section{Errors due to registration of intersection points}

The horizontal coordinates of the points where the profiles intersect the contour lines were determined using a digitizing table and suitable numerical algorithms (personal communications from B. Rabus, 1994- 96). The horizontal errors in map registration and in the contour-profile intersections are both about $10 \mathrm{~m}$ according to Echelmeyer and others (1996) and Sapiano and others (1998). Repeat tests were done to confirm these error estimates for our data. We found that the combined error for registration and intersectionpoint selection was about $13 \mathrm{~m}$, which is nearly the same as that quoted by those authors, assuming the errors are inde- pendent. The vertical error is the product of the horizontal error and the tangent of the surface slope; in steep areas it can be $10 \mathrm{~m}$ or more. A detailed test on one glacier indicated that the mean vertical error was $3 \mathrm{~m}$ for 27 intersections of varying slope.

As already noted, the Harding Icefield is located within two UTM zones. This makes our comparison with the maps more complicated and introduces additional errors because of larger map distortion near the zone boundaries. Tests indicate that there could be an additional horizontal error of about $30 \mathrm{~m}$ near the boundary, or $1-6 \mathrm{~m}$ in the vertical, depending on slope.

\section{Summary of elevation-change errors}

The elevation changes determined by comparison of the profiles with the maps are subject to each of the random errors mentioned and an additional error of a few meters in the snow-depth corrections. Combining all these errors, assuming that they are independent, gives an estimate for the total error in the seasonally corrected elevation change (ice thickness) at each contour intersection. For the upper regions, above $1000 \mathrm{~m}$ (generally above the snowline), this random error is $52 \mathrm{~m}$. In the lower regions (generally in the ablation areas) it is $21 \mathrm{~m}$. There may possibly be unquantified systematic errors as well, especially in the upper regions.

\section{LONG-TERM ELEVATION GHANGES}

The glaciers profiled in this study span a range of glacier type, aspect, size and slope. There are three land-terminating glaciers, four that now terminate in lakes, four tidewater glaciers and two that have recently retreated from tidewater. Here we choose three representative glaciers for detailed discussion; later we compare the elevation changes for all the glaciers. (The detailed results for all the glaciers are further described by Adalgeirsdóttir, 1997.) These three glaciers are Exit on the northeastern side of the icefield, Kachemak on the southwest and McCarty, a tidewater glacier on the south (Fig. lb). The profile and contour elevations are shown in Figures 2-4, along with the elevation change between them. The black diamonds show the mean value $(0.1 \mathrm{~m})$ of all elevation differences at profile-contour crossings above $1000 \mathrm{~m}$ on the main icefield and above $1200 \mathrm{~m}$ to the south, an approximation that we use in the volume-change calculations discussed below.

Exit Glacier is a small, relatively steep glacier that terminates on land on the northeastern side of the icefield, and it has a northeastern aspect (Fig. 1). This glacier has been the subject of study by Kenai Fjords National Park (Rice, 1987; personal communication from M. Tetrau, 1996) because of its easy access. The terminus has retreated about $500 \mathrm{~m}$ since $1950 / 1951$, and it thinned $80-90 \mathrm{~m}$ in the lower regions (Fig. 2). At the highest elevations, the surface appears to have changed shape since the maps were made, but the contrast in the mapping photographs was poor there and the contours may be poorly drawn.

Kachemak Glacier is a land-terminating glacier with western aspect on the southwestern side of the icefield (Fig. 1). Bredthauer and Harrison (1984) measured thickening on the upper glacier and a retreat of the terminus between 1952 and 1979. The photographic contrast for its upper region was better than for most glaciers on the northern icefield, 

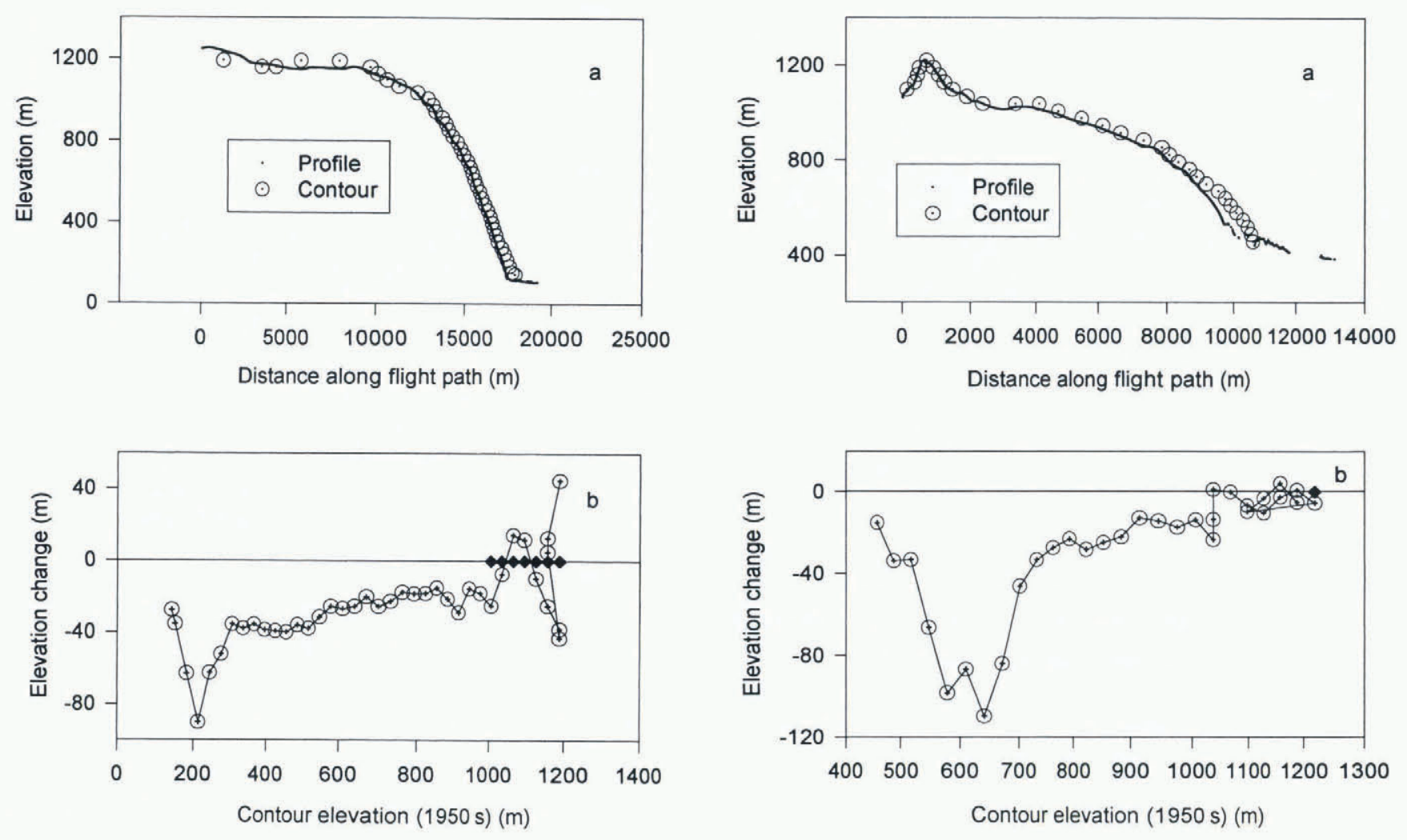

Fig. 2. Exit Glacier: (a) Profile (1994) and contour (1950) 1951) elevations (MSL) along the profile. (b) Elevation change, 1950/1951 to 1994. The diamonds show the mean elevation change of all icefield contours above 1000/1200 m used to calculate the volume change in one scenario.

and consequently there is considerably less scatter in the elevation changes there. The glacier thinned by about $20 \mathrm{~m}$ except at the highest elevations, where the thinning was smaller, and at the terminus, where the thinning was large (100 m; Fig. 3). The terminus retreated about $900 \mathrm{~m}$.

McCarty Glacier is a tidewater glacier with southern aspect on the south side of the icefield. It retreated about $690 \mathrm{~m}$ from 1950 to 1996, but it has actually been advancing since 1960 (Post, 1980b). Its elevation-change profile is different from that of most of the other glaciers, in that the higher elevations of the glacier thickened by $20-40 \mathrm{~m}$, while it thinned at lower elevations (Fig. 4). At the present terminus the thinning was about $80-100 \mathrm{~m}$. Where the glacier retreated, the elevation change was estimated from bathymetric maps (Post, 1980b).

\section{Elevation changes on the entire icefield}

The icefield was divided into four regions, and the elevation changes for the glaciers in each region were compared (Figs 5-8). All contour crossings above $1000 / 1200 \mathrm{~m}$ are shown in Figure 9. Open symbols represent contour crossings where the profile was interpolated because of a lack of profile data caused by a lake, ocean or extremely rough surface. Where there was more than one profile on a glacier, the average elevation change at a contour is shown.

The western region of the icefield consists of land-terminating glaciers with western aspect, and they are all in the precipitation shadow of the icefield (Fig. 1). The elevation changes at the lowest elevations (Fig. 5) differ among the glaciers, as expected because their termini are at different elevations and they retreated different amounts. At higher

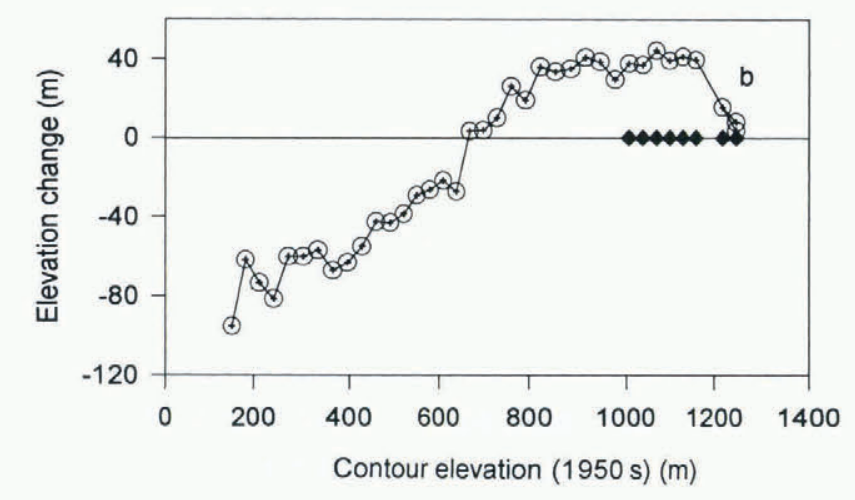

Fig. 3. Kachemak Glacier. (a) Profile (1996) and contour (1952) elevations (MSL) along the profile. (b) Elevation change, 1952-96. Diamonds as in Figure 2.

elevations, the two southernmost glaciers, Kachemak and Dinglestadt, have similar elevation changes, while Tustumena and Chernof show larger changes. There is considerable scatter in the elevation change in the upper regions of

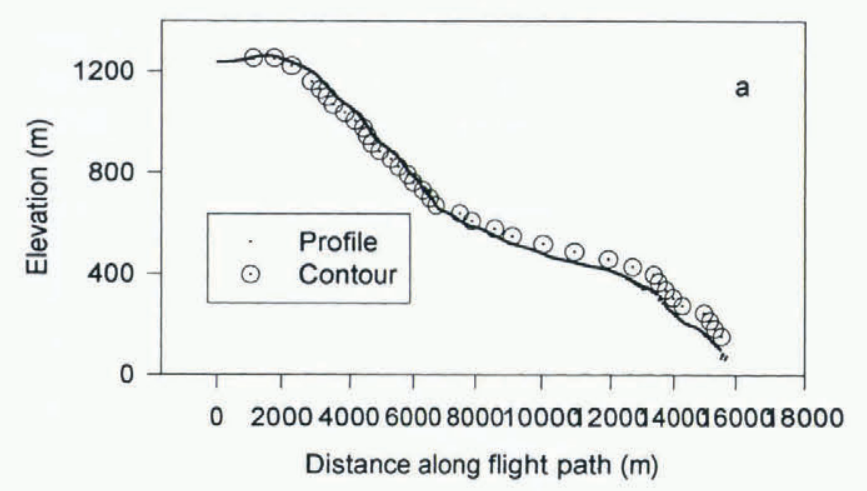

Fig. 4. McCarty Glacier. (a) Profile (1996) and contour (1950) elevations (MSL) along the profile. (b) Elevation change, 1950-96. Diamonds as in Figure 2. 


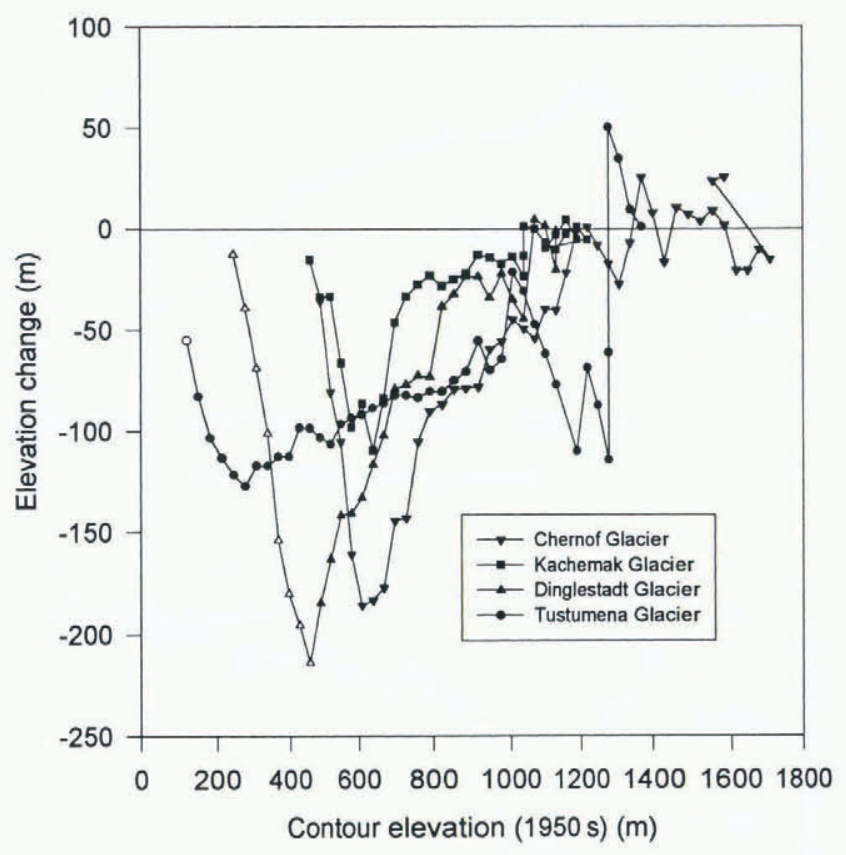

Fig. 5. Elevation change for the west side of the icefield; open symbols represent estimated elevation change where the profile was interpolated.

any one glacier. For example, the $\sim 1300 \mathrm{~m}$ contour on Tustumena Glacier was crossed three times during one flight, with elevation changes ranging from $-120 \mathrm{~m}$ to $+45 \mathrm{~m}$ (!), as shown in Figures 5 and 6.

Two land-terminating glaciers on the northern part of the icefield, Skilak and Exit, show similar elevation changes at higher elevations (Fig. 6), but they have much smaller elevation changes than Tustumena Glacier to the south. Skilak Glacier retreated more than $3 \mathrm{~km}$, while Exit retreated only about $500 \mathrm{~m}$. This difference can be seen in the elevation changes at lower elevations.

The eastern region of the icefield has two tidewater glaciers, Aialik and Holgate, and one, Bear, that was a tidewater glacier but now terminates in a lagoon. These glaciers

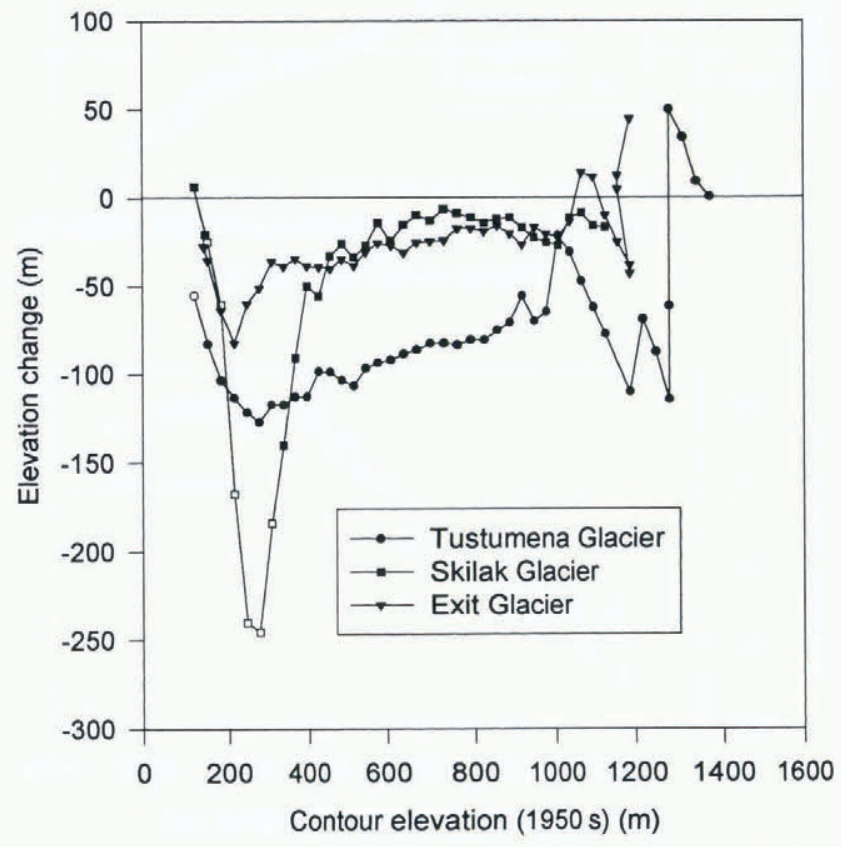

Fig. 6. Elevation change for the north side of the icefield; open symbols represent estimated elevation change where the profile was interpolated.

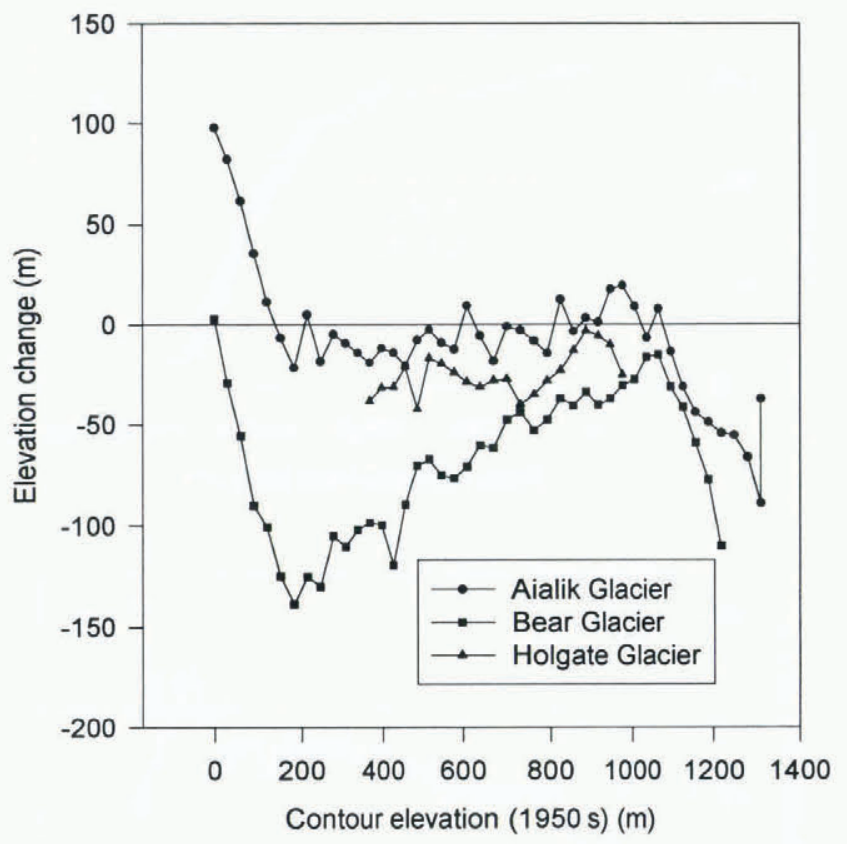

Fig. 7. Elevation change for the east side of the icefield.

receive more precipitation than those to the north and west. The two tidewater glaciers thinned less than Bear Glacier (Fig. 7), and the thinning on Bear was similar to that on Tustumena Glacier (Fig. 6). The elevation change for Aialik Glacier, which advanced slightly over this time period, was near zero, except at higher elevations. There was an apparent strong thinning at the head of Aialik and Bear Glaciers, but these data may be in error due to poorly defined contours there.

Four glaciers were profiled in the southern region. Two are tidewater, McCarty and Northwestern, and the other two, Northeastern and Little Dinglestadt, have retreated from tidewater and now terminate on land. Figure 8 shows the difference between McCarty and the other glaciers: it has thinned at lower elevations but thickened above $600 \mathrm{~m}$. Northeastern and Northwestern Glaciers thinned at higher

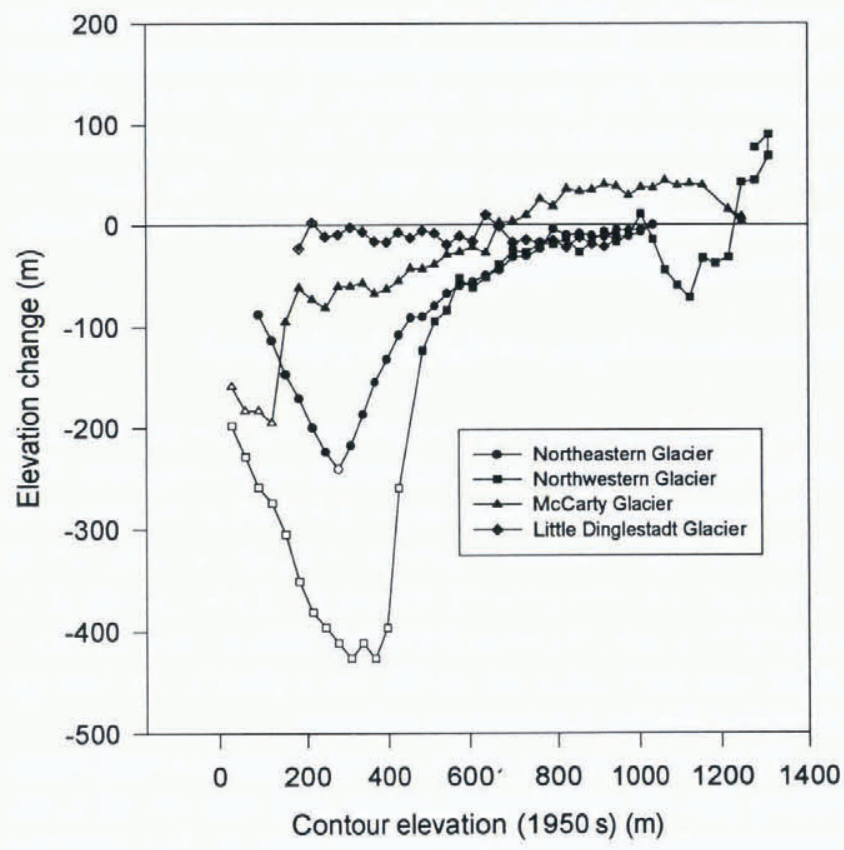

Fig. 8. Elevation change for the south side of the icefield; open symbols represent estimated elevation change (from Post, $1980 \mathrm{~b}, \mathrm{c}$ ) and where the profile was interpolated. 


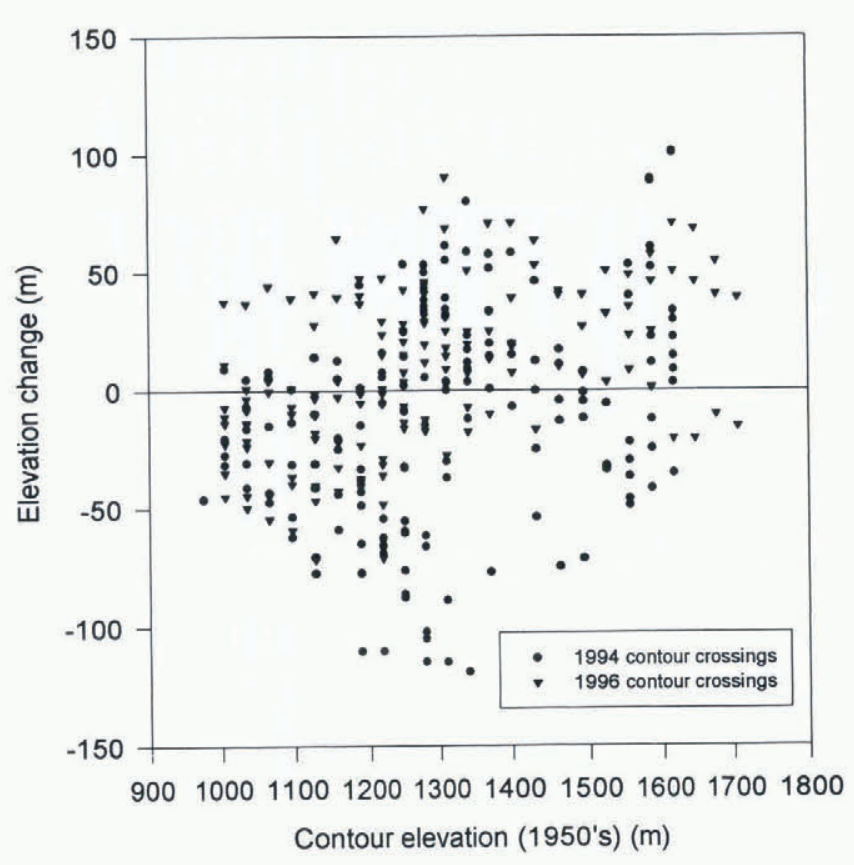

Fig. 9. Elevation change for the upper regions of the icefield.

elevations, but at lower elevations the difference in retreat can be seen: Northwestern retreated $4.2 \mathrm{~km}$, while Northeastern retreated only $1.3 \mathrm{~km}$ onto land. The open symbols shown for McCarty and Northwestern Glaciers are elevation changes estimated using the bathymetric maps of Post $(1980 \mathrm{~b}, \mathrm{c})$; this thinning is equal to the elevation of the contour plus the fjord depth.

Figure 9 shows the elevation changes along the upper, flatter regions of the icefield. All contour crossings above $1000 \mathrm{~m}$ elevation for the main icefield and above $1200 \mathrm{~m}$ for the southern area are shown. These elevations are our estimate of where surface definition was lost on the mapping photographs. The mean elevation change for all these contour crossings was $0.1 \mathrm{~m}$, with a standard deviation about the mean of $45.5 \mathrm{~m}$. As mentioned earlier, this large scatter is a measure of the map accuracy in the upper regions; it is likely due to poorly drawn contours.

Transects across the icefield can be drawn using our profile data (Adalgeirsdóttir, 1997). East-west transects indicate large $(\sim 100 \mathrm{~m})$ thinning on the western, lee side of the icefield, while the eastern, more maritime side has only a slight thinning. However, these differences may be due, in part, to different glacier sizes and surface slopes. Northsouth transects show little difference in elevation change between 400 and $800 \mathrm{~m}$ elevation.

\section{SHORT-TERM ELEVATION CHANGES}

The accuracy of the profiling system allows us to obtain elevation changes over shorter periods of time by repeat profiling. We have done this for Skilak and Exit Glaciers. They were profiled both in 1994 and in 1996, Skilak on the same calendar day, and Exit two calendar days later in 1996. A second profile was also flown on Holgate Glacier in 1996, but no attempt was made to repeat the 1994 ground track, so the two profiles do not overlap as much as they did on the other two glaciers. We have also compared the profile elevation at 11 points on the upper icefield where 1996 and 1994 profiles crossed (shown as circles in Figure la). All
Table 5. Elevation difference between profiles measured in 1994 and 1996

\begin{tabular}{lcccc}
\hline Glacier & $\begin{array}{c}\text { Number of } \\
\text { points }\end{array}$ & $\begin{array}{c}\text { Mean elevation } \\
\text { change }\end{array}$ & $\begin{array}{c}\text { Standard } \\
\text { deviation about } \\
\text { the mean }\end{array}$ & $\begin{array}{c}\text { Standard } \\
\text { deviation of the } \\
\text { mean }\end{array}$ \\
& & $\mathrm{m}$ & $\mathrm{m}$ & $\mathrm{m}$ \\
\hline Exit & 958 & -3.5 & 0.6 & 0.02 \\
Holgate & 17 & -5.1 & 0.1 & 0.03 \\
Skilak & 366 & -3.2 & 0.5 & 0.03 \\
Icefield & 11 & -4.2 & 0.7 & 0.20 \\
\hline
\end{tabular}

points that were within $1 \mathrm{~m}$ of each other were compared on Skilak, Exit and Holgate glaciers, while only the two closest points (usually within $1 \mathrm{~m}$ ) were compared on the upper icefield.

Elevation differences and their errors from 1994 to 1996 are listed in Table 5; these are the averages among the different crossing points. The average rates of elevation change over the 2 year period for Exit, Skilak and Holgate glaciers were $-1.8,-1.6$ and $-2.5 \mathrm{~m} \mathrm{a}^{-1}$, respectively. For the upper icefield, the average rate of elevation change was $-2.1 \mathrm{~m} \mathrm{a}^{-1}$. The climatic significance of these short-term changes is discussed following.

\section{TERMINUS CHANGES}

Terminus changes from the 1950 s to the 1990 s are listed in Table 6. To identify the terminus in our profiles, we used the position of a "kink" in the profile (where the slope changes) or the time when the terminus was reported in the aircraft. All the land-terminating glaciers are retreating; Skilak and Dinglestadt retreated the most. All of the tidewater glaciers except Aialik and McCarty are also retreating. Bear and Northeastern Glaciers have retreated onto land.

Viens (1995) found that most of the tidewater calving glaciers in Alaska have retreated over the last 200 years, likely in response to a global rise in ELA. McCarty and Northwestern Glaciers started retreating in 1900 after a long, slow advance, while the terminus of Aialik Glacier has been in the same position since 1900 (Post, 1980a, b, c; Wiles and others, 1995).

We determined recent variations in terminus position for four of the tidewater glaciers (Holgate, Holgate's neighbor, Aialik and McCarty) using aerial photographs (Adalgeirsdóttir, 1997). These glaciers retreated between 1950 and 1978, advanced between 1978 and 1984 and, except for Holgate, continued to advance from 1984 to 1993 . McCarty Glacier retreated $1400 \mathrm{~m}$ between 1950 and 1978 . It has advanced $700 \mathrm{~m}$ since 1978 , but has not yet reached the 1950 s position. The other three glaciers had smaller terminus variations of about $100-300 \mathrm{~m}$.

The retreat rate is clearly related to water depth. Northwestern Glacier retreated at $36 \mathrm{~m} \mathrm{a}^{-1}$ from 1900 to 1927 in 20-100 $\mathrm{m}$ deep water on the terminal shoal, but after it reached deeper water $(150-300 \mathrm{~m})$ the rate increased to $460 \mathrm{~m} \mathrm{a}^{-1}$ (Post, 1980c). McCarty retreated at a rate of $25 \mathrm{~m} \mathrm{a}^{-1}$ in shallow water, then accelerated to $800 \mathrm{~m} \mathrm{a}^{-1}$ in deeper water (Post, 1980b). 
Table 6. Changes of each glacier from 1950s to 1990s, along with glacier area at time of mapping. Also included (in italics) are regions not profiled where elevation changes were extrapolated from neighboring glaciers

\begin{tabular}{|c|c|c|c|c|c|c|c|}
\hline \multirow[t]{2}{*}{ Glacier } & Map area & $\Delta A^{\mathrm{a}}$ & $\begin{array}{l}\text { Terminus } \\
\text { change }^{\mathrm{b}}\end{array}$ & $\begin{array}{c}\Delta V^{c} \\
\text { contour }\end{array}$ & $\underset{\text { with } 0 m}{\Delta V^{\mathrm{d}}}$ & $\langle\Delta z\rangle^{\mathrm{e}}$ & $\langle b\rangle^{\mathrm{f}}$ \\
\hline & $\mathrm{km}^{2}$ & $\mathrm{~km}^{2}$ & $\mathrm{~m}$ & $\mathrm{~km}^{3}$ & $\mathrm{~km}^{3}$ & $\mathrm{~m}$ & $\mathrm{~m}$ \\
\hline Aialik & 118.0 & 0 & $540^{2}$ & -2.6 & 0.003 & -11.0 & -0.2 \\
\hline Bear & 228.5 & -8.75 & $-1550^{2}$ & -9.7 & -7.5 & -38.4 & -0.7 \\
\hline Exit $^{1}$ & 42.8 & -0.25 & $-490^{2}$ & -0.1 & -0.14 & -2.6 & -0.1 \\
\hline Holgate $^{\prime}$ & 64.3 & -0.25 & $-260^{2}$ & -1.3 & -0.8 & -16.3 & -0.3 \\
\hline Skilak ${ }^{1}$ & 217.0 & -5.63 & $-3200^{3}$ & -0.9 & -1.1 & -4.5 & -0.1 \\
\hline Tustemena & 296.7 & -1.75 & $-690^{2}$ & -8.9 & -6.0 & -25.1 & -0.5 \\
\hline Chernof & 95.3 & -1.00 & $-(750)^{3}$ & -2.3 & -2.0 & -22.6 & -0.4 \\
\hline Dinglestadt & 79.4 & -4.25 & $-2300^{4}$ & -2.7 & -2.4 & -32.4 & -0.6 \\
\hline Kachemak & 54.9 & -0.75 & $-900^{4}$ & -0.9 & -0.9 & -16.3 & 0.3 \\
\hline $\begin{array}{l}\text { Little } \\
\text { Dinglestadt }\end{array}$ & 31.5 & -0.5 & $-(370)^{5}$ & -0.6 & -0.5 & -18.6 & -0.4 \\
\hline Mc Carty & 108.6 & -1.38 & $-690^{5}$ & +1.5 & -0.2 & +6.2 & 0.1 \\
\hline Northeastern & 15.4 & -1.63 & $-1350^{2}$ & -1.4 & -1.4 & -97.1 & -1.8 \\
\hline Northwestern & 66.25 & -8.00 & $-4200^{5}$ & -5.0 & -5.0 & -80.2 & -1.5 \\
\hline east of Skilak & 83.8 & & & $(-2.6)$ & $(-0.3)$ & $(-17.4)$ & $(-0.3)$ \\
\hline west of Skilak & 122.7 & & & $(-1.6)$ & $(-0.8)$ & $(-9.9)$ & $(-0.2)$ \\
\hline Lowell & 17.5 & & & $(-0.04)$ & $(-0.1)$ & $(-4.0)$ & $(-0.1)$ \\
\hline Pederson & 32.0 & & & $(-0.3)$ & $(-0.1)$ & $(-5.0)$ & $(-0.1)$ \\
\hline Total & 1674.7 & -34.1 & & -39.4 & -29.2 & $\begin{array}{l}-20.6 \\
\text { ave.) }\end{array}$ & $\begin{array}{r}0.4 \\
\text { (ave.) }\end{array}$ \\
\hline
\end{tabular}

a Area change from 1950 s to 1990 s.

${ }^{\mathrm{b}}$ Terminus changes from $1950 \mathrm{~s}$ to $1990 \mathrm{~s}$.

Volume changes computed with the elevation change from the maps to the profiles, using all data.

Volume changes with $0 \mathrm{~m}$ elevation changes above $1000 \mathrm{~m}$ on main icefield and $1200 \mathrm{~m}$ on south side.

Area-average elevation changes using the average $\Delta V$ of the two scenarios divided by the average area between 1950s and 1990s (ice equivalent).

'Long-term average annual mass balance calculated by multiplying the area mean elevation change by density and dividing by the time period (water equivalent).

Profile data from 1994. For Holgate Glacier the terminus position from 1996 was used.

${ }^{2}$ The kink in the profile used to estimate terminus change.

${ }^{3}$ No profile data at the terminus; timing in the aircraft used.

${ }_{5}^{4}$ Kink in profile and aircraft timing used to estimate terminus position.

"Profile ends before terminus; an estimate is used.

\section{VOLUME-GHANGE CALGULATIONS}

To calculate the volume change of individual glaciers and of the entire icefield, we must first determine the margins and ice divides for each glacier. This is a difficult task, in part because map errors in the upper icefield make it difficult to define the ice divides. Once the boundaries are defined, the large map errors on the upper icefield will be amplified in their effect on the volume-change calculations because a significant fraction of each glacier lies in this zone of large errors.

Echelmeyer and others (1996) and Sapiano and others (1998) describe a method for volume-change calculation in which new contour lines are constructed from the profiles and the glacier's area is allowed to change as it thins or thickens. The original map is compared to the newly constructed one to determine the volume change. For Harding Icefield we used a simpler method because there are large areas of the icefield where no area change occurred and because there are large areas that were not profiled, where

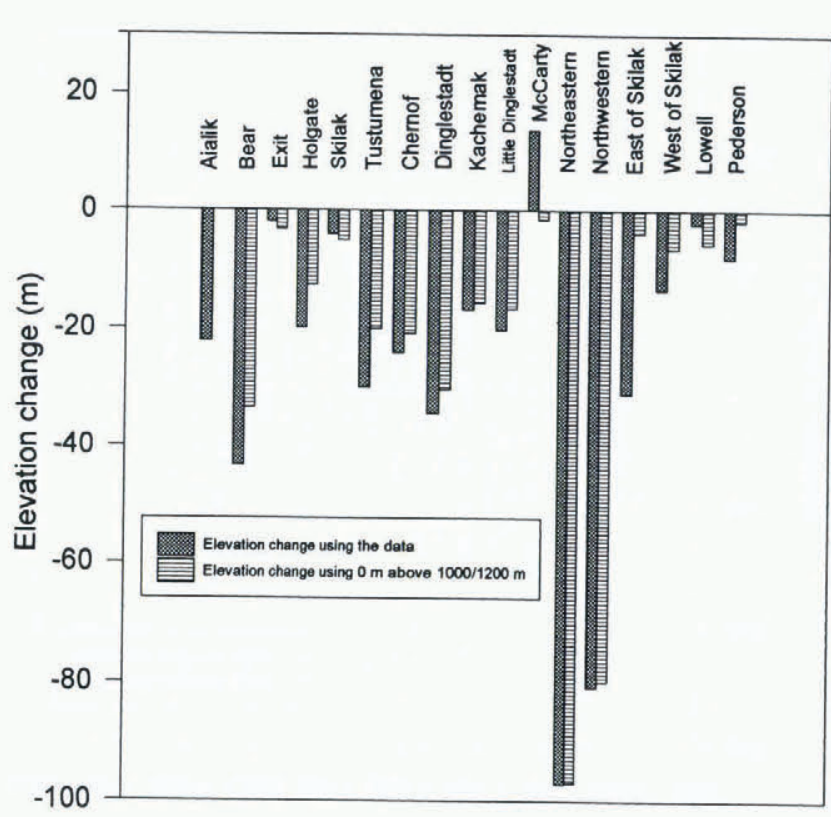

Fig. 10. Area-averaged elevation changes for each glacier calculated with the two scenarios for change on the upper icefield: actual contour crossings and with $0 m$ elevation change above $1000 / 1200 \mathrm{~m}$ (MSL). The dashed line is the area-average elevation change for the whole icefield.

we felt their method could not be applied with any degree of accuracy. However, we did estimate the change in area near the terminus of each glacier. This area change was then subtracted from the original area to give an estimate of recent glacier area (Table 6). We then assumed that the elevation change within a given elevation band was constant across a particular glacier. This elevation change was multiplied by the map area within that band, and these volume changes were summed to give the total volume change for a glacier. The area-average thickness change was calculated by dividing the total volume change by the average of the old and the new areas.

Some areas listed in Table 6 (Lowell and Pederson Glaciers and the areas to the east and west of Skilak Glacier) were not actually profiled. In these areas we estimated the volume change by using data from adjacent glaciers in combination with actual area distributions. This allowed us to calculate a more complete volume change for the entire icefield.

The upper icefield requires special consideration in the volume-change calculation because of the large scatter in the elevation changes there. We cannot quantify the errors involved. Instead we have estimated the sensitivity of the volume change to any such errors by computing the volume changes under two scenarios: (i) using the actual elevation changes determined from the profile-to-map comparisons (Fig. 9) with their large scatter, and (ii) assuming no elevation change above $1000 \mathrm{~m}$ on the main icefield and above $1200 \mathrm{~m}$ to the south. The average elevation change of $0.1 \mathrm{~m}$ for all the contour crossings in this area supports the second scenario (shown as diamonds in Figures 2-4). The results of these two scenarios are given in Table 6, and the area-average elevation changes are shown in Figure 10. The means of these two area-average elevation changes are shown by each glacier in Figure lb.

It should be noted that area-average elevation changes in Table 6 and Figures $1 \mathrm{~b}$ and 10 were calculated using our measured elevation changes from the date of the maps to 
that of the profiles. If Sorge's law applied to the snow and ice that was lost by ablation then the long-term average mass balance (in water equivalent), $\langle b\rangle$, would be obtained by multiplying the area-average elevation change by a density of $900 \mathrm{~kg} \mathrm{~m}^{-3}$ and dividing by the appropriate time interval. However, this law does not strictly hold when old firn is ablated (Krimmel, 1989), and to correct for this we use a density of $\sim 850 \mathrm{~kg} \mathrm{~m}^{-3}$, following Sapiano and others (1998). This value of $\langle b\rangle$ is given in the last column of Table 6 .

Comparison of the results from the different scenarios shows that scenario (i), with the actual elevation changes, gives a more negative volume change on all but Mc Carty Glacier. In some cases the differences are small, either because the area at higher elevations is smaller or possibly because the contours are reasonably accurate in some of these regions. In other cases, such as Aialik, Bear and McCarty glaciers, the differences are quite large, implying either that the measured elevation changes in the upper areas were significantly different from the mean, or that these contours were incorrect. It is useful to note, however, that all the resulting volume changes are negative, except that of McCarty Glacier, and the magnitudes of the changes are significantly larger than the differences between the scenarios.

The volume changes of Northwestern and Northeastern Glaciers appear to be abnormally large. For Northwestern Glacier this can be explained by its retreat in a deep fjord, where the thickness of the ice was great. The area distribution is different for Northeastern Glacier than for the other glaciers. It has a large fractional area at low elevations $(200-$ $500 \mathrm{~m}$ ), and the elevation changes at these elevations are large.

We estimated the total volume change for the entire icefield by summing the average of the volume changes of the two scenarios for each glacier, along with the estimated changes for these areas that were not profiled. The areaaverage elevation change for the entire icefield is then given by this total volume change divided by the average of the old and new total areas. The total volume change is about $-34 \mathrm{~km}^{3}$, and the area-average elevation change is $-21 \mathrm{~m}$. Because of unknown errors in the maps, we cannot specify an actual error for this elevation change. However, we can obtain an idea of the error by looking at the difference in area-average elevation changes calculated using the two scenarios. The mean difference between the two scenarios was $5 \mathrm{~m}$. We use this value to estimate an error of $5 \mathrm{~m}$ in the area-average elevation change. This estimated error is significantly smaller than the magnitude of the area-average elevation change, so we conclude that Harding Icefield has been losing volume during the $\sim 43$ year interval between the time of the map photography and our profiling.

\section{Use of digital elevation model to calculate volume change}

The area distribution for each glacier was determined using the digital elevation model (DEM) of Alaska, which gives elevation on a $90 \mathrm{~m}$ grid. It is important to note that the DEM was calculated from the original maps (USGS, 1990), so it has all the errors inherent in these maps. The boundary of each glacier was digitized from the topographic maps, and the DEM was masked using this boundary. The area distribution of each glacier was then determined by counting pixels within each elevation band.
An alternative method for determining the elevation changes using this DEM was developed by H. Li and C. Lingle (personal communication, 1997). Our profiles were directly compared to a $30 \mathrm{~m}$ interpolation of the DEM, giving the elevation change at each DEM pixel along the profile. This method could possibly lead to substantial savings in time and effort, as it would make it unnecessary to digitize the map contours. To evaluate the quality of the DEM relative to the maps, and of Li and Lingle's method, we compared our profile-to-map changes with those calculated using their method. In most cases, the local elevation changes compared quite well, but in a few cases there were large discrepancies. Figure 11 shows an example of the elevation changes calculated using the two methods. The comparison on Northwestern Glacier is quite good, while on Northeastern Glacier the DEM is more than $100 \mathrm{~m}$ different than the map for a significant length of the profile. The average difference between the two methods for all the glaciers (map minus DEM) was $-4.4 \pm 1.0 \mathrm{~m}$. This is a significant error, and therefore the DEM must be used with caution. In our analyses we used the DEM only for determining the area distribution for each glacier.
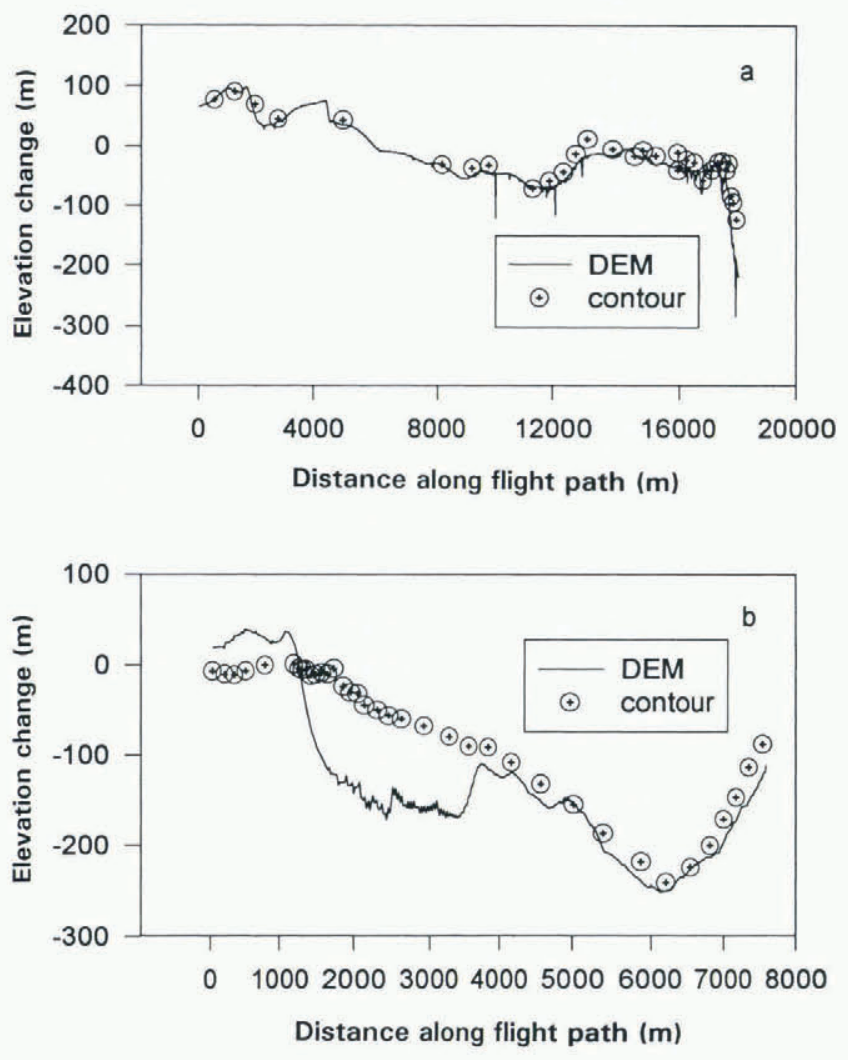

Fig. 11. Comparison of elevation changes relative to the topographic maps (circles) and relative to the DEM (line): (a) Northwestern Glacier, (b) Northeastern Glacier.

\section{DISGUSSION}

The stability of an icefield is dependent on the distribution of area in the accumulation area with respect to the ELA. The ratio of the glacier area above $1000 / 1200 \mathrm{~m}$ (our estimate of the ELA in the 1950s; Viens (1995) estimated lower values for some of the glaciers) to the entire icefield is 0.70 . Most of this accumulation area is a few hundred meters above the elevation of the equilibrium line. A $200 \mathrm{~m}$ rise in ELA would decrease the AAR to 0.48 . This indicates that 
the icefield is relatively stable to small shifts in the ELA (Bodvarsson, 1955). This ratio also defines the area where the elevation changes are ambiguous due to the lack of contrast in the photos.

Harding Icefield consists of a variety of glaciers flowing from a common accumulation area. The icefield is only about $80 \mathrm{~km}$ long and $50 \mathrm{~km}$ across, so we expect that the same large-scale (synoptic) climatic variations would affect the entire icefield. However, there are differences in both temperature and precipitation between the more maritime eastern side and the more continental western side of the icefield. Our results allow us to illuminate any differences in the volume changes on these two parts of the icefield, as well as to address related questions, such as: How do different types of glaciers respond to a similar synoptic-scale climate change, and how do different characteristics of glaciers influence their behavior? To this end, we investigated the correlation between the area-averaged elevation change and different glacier parameters, with the following results:

Type of glaciers: We find no obvious difference in areaaveraged elevation change between tidewater, lake and land-terminating glaciers. Most of the tidewater glaciers thinned by $-16 \pm 7 \mathrm{~m}$ (excluding Northeastern and Northwestern Glaciers), while the land-terminating glaciers thinned by $-17 \pm 5 \mathrm{~m}$.

Location on icefield and aspect: The glaciers on the south side of the icefield appear to have thinned more than those on the north, and, related to this, glaciers with southern aspect show more thinning than those with northern aspect. Although not statistically significant, these findings may support the suggestion of Mercer (1961) that the ELA has risen more on the south side of the icefield than on the north from 1909 to 1950. Surprisingly, there were no substantial differences between glaciers on the west (continental) and those on the east (maritime).

Area and length: There is no statistically significant correlation between elevation change and glacier area or length. However, the larger glaciers appear to have thinned slightly more than the smaller ones, probably because the longer ones have more area at lower elevations.

Surface slope: A positive correlation between average thickness change and surface slope might be expected because glaciers that have smaller slopes tend to have larger changes in AAR with a change in ELA than those with steeper slopes. We find that surface slope shows a slightly better correlation with elevation change than the other glacier parameters do. This is especially true if the two somewhat anomalous glaciers, Northeastern and Northwestern, are excluded from the regression analysis (see Fig. 12).

Terminus changes: We examined the correlation between the elevation change and the fractional change in length $(\Delta L / L)$. If Northeastern and Northwestern Glaciers are included it appears that the glaciers that thinned the most retreated the most, as expected. However, the correlation is strongly dependent on these two glaciers and, in any case, is poor (Fig. 12). A poor correlation between thinning and retreat was also found by Echelmeyer and others (1996) and Sapiano and others (1998). For non-
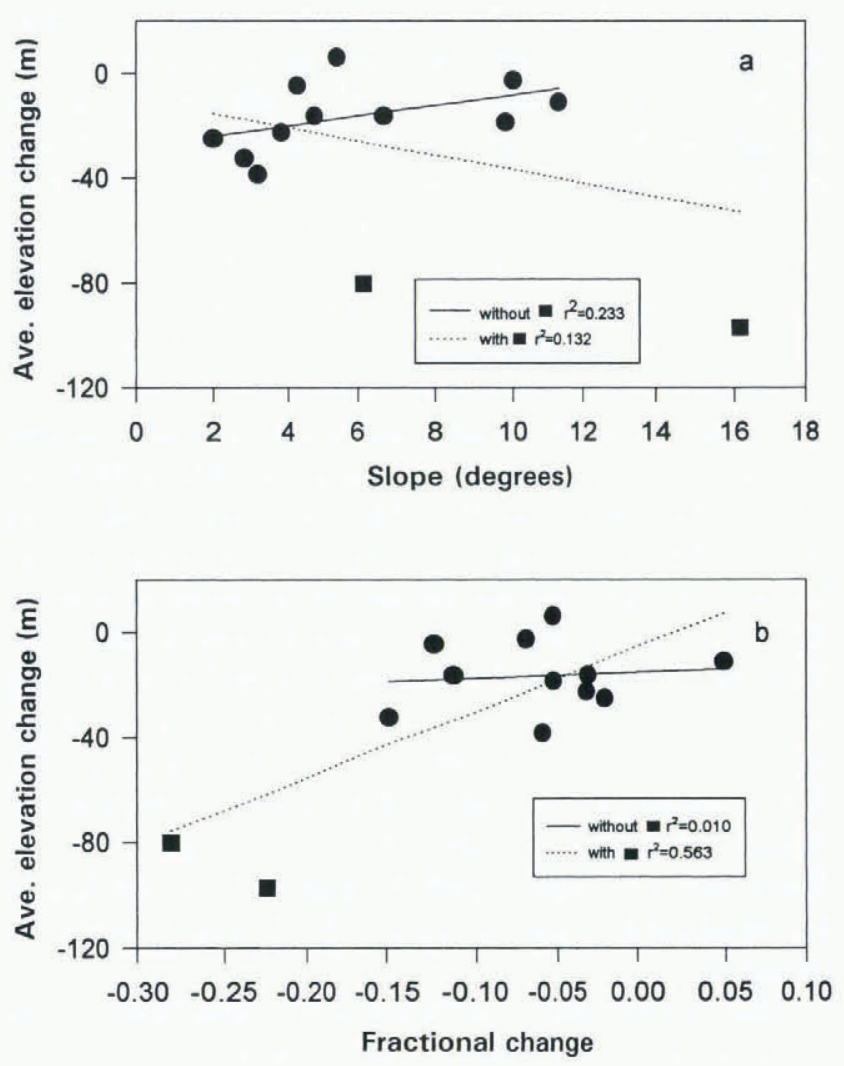

Fig. 12. Regression analyses: (a) area-average elevation change us slope; (b) area-average elevation change us fractional length change. Two best-fit lines are shown in each figure, the solid line is calculated without Northwestern and Northeastern Glaciers (squares) and the dashed line is with those two glaciers included.

tidewater glaciers, Hacberli and Hoelzle (1995) found a better correlation between fractional length change and average mass balance if a measure of glacier response time (Jóhannesson and others, 1989) is taken into account. However, we do not have the necessary information (specifically, the ice thickness) to test this relation.

In all, there were no statistically significant single-variable correlations between the area-averaged elevation change and glacier parameters. This is true even if only the more accurate map comparisons below 1000/1200 m elevation are used. It may be that the situation is more complex. For example, McCarty Glacier, the only glacier with a positive elevation change over the $\sim 43$ year interval, is presently an advancing tidewater glacier with southern aspect on the south side of the icefield. In the same fjord, Little Dinglestadt Glacier, with an eastern aspect, retreated from tidewater and had an elevation change close to the mean for the entire icefield. Just east of McCarty are Northeastern and Northwestern Glaciers, both of which have large negative elevation changes. Northeastern Glacier has retreated onto land, and Northwestern Glacier retreated $4 \mathrm{~km}$ but still terminates in tidewater.

\section{Can one glacier be representative for the icefield?}

The glaciers of Harding Icefield had a wide range of areaaveraged elevation change, from near zero to about $-90 \mathrm{~m}$, with an average change of $-23 \pm 6 \mathrm{~m}$. The results shown in Figure 10 indicate that the changes on eight of the glaciers were close to the area-average change of $-21 \mathrm{~m}$ for the ice- 
field as a whole. Some of the glaciers are tidewater and others are land-terminating. This indicates that one glacier could be chosen to be representative of the icefield, but its choice requires careful consideration. The scatter in the glacier changes about this icefield average is larger than that observed by Rabus and Echelmeyer (in press) for a glacierized region of Arctic Alaska, indicating that the choice of a representative glacier for Harding Icefield is more difficult than for that region.

We can compare our results for the Harding Icefield glaciers with those for two nearby glaciers, both of which are land-terminating and relatively small. Bear Lake Glacier, $20 \mathrm{~km}$ northeast of Exit Glacier, thinned $12.5 \mathrm{~m}$ over the last 37 years (Echelmeyer and others, 1996; Sapiano and others, 1998), or by about $14.5 \mathrm{~m}$ extrapolated to our 43 year period. Wolverine Glacier, about $50 \mathrm{~km}$ northeast of Exit Glacier, had an average annual balance of about $-0.25 \mathrm{~m}$ (water equivalent) from 1966 to 1995 (USGS, 1997). This extrapolates to about $13 \mathrm{~m}$ of ice thinning over our 43 year period. These elevation changes are somewhat smaller than the thinning of $21 \mathrm{~m}$ estimated for Harding Icefield. However, given the large uncertainties in both measurements, they are consistent. It is interesting to note that the elevation changes at high elevations for these two glaciers are somewhat more accurate than those on the Harding Icefield because the maps are better. Bear Lake Glacier shows thickening at these higher elevations (Sapiano and others, 1998; this leads to the smaller area-averaged thinning.

\section{Short-term elevation changes}

The short-term elevation changes between 1994 and 1996 show that the glaciers are presently thinning (Table 5), and because the errors are small these elevation changes are well resolved. For Exit Glacier the area-average elevation change over these 2 years is nearly constant with elevation (i.e. area average equals local change). This is in contrast to the decrease with elevation shown by the long-term elevation change (e.g. Fig. 2). Our 1996 measurements on Skilak Glacier were limited to the elevation range $600-1100 \mathrm{~m}$. Over that elevation range, the 2 year change was also nearly constant and, thus, we assumed that the change over the rest of the glacier was constant as well. Two-year elevation changes on the upper icefield decrease from $-4.5 \mathrm{~m}$ in the south to $-3.0 \mathrm{~m}$ in the north.

When this short-term elevation change is compared to the area-average elevation change for these glaciers over the last $\sim 43$ years (Table 6 , column 6 ), we find that the recent thinning rate is an order of magnitude larger than that measured over the longer interval, and about three times larger than that determined for the icefield as a whole. However, this increase in thinning rate may not have climatic significance. Comparison of the apparent increased rate of thinning on the Harding Icefield with the standard deviation of Wolverine Glacier's annual mass balance record $\left(\sigma=1.25 \mathrm{~m} \mathrm{a}^{-1}\right)$ implies that our measured elevation changes may only reflect the scatter in annual balance, being due to short-term fluctuations in snowfall and ablation. However, it is interesting to note that a similar accelerated thinning rate has been found on McCall Glacier in Arctic Alaska (Rabus and others, 1995; Rabus and Echelmeyer, in press).

\section{CONCLUSIONS}

Airborne altimetry profiling is an efficient and accurate way to measure elevation changes on glaciers. We found the accuracy of the system to be about $0.2 \mathrm{~m}$ when GPS conditions are good, meaning sufficient satellite numbers and geometry. We determined elevation and volume changes for 13 glaciers and the upper icefield by comparing the profiles to topographic maps. Errors in these changes are subject to large inaccuracies in the maps at higher elevations; these are mainly due to a lack of contrast in the mapping photographs. The published accuracy of the maps (15 $\mathrm{m}$ in our case) appears to apply to the lower elevations of the icefield, but above the snowline the errors are about three times larger $(\sim 50 \mathrm{~m})$.

Harding Icefield has been thinning and shrinking since the 1950s. We estimate that the total volume loss of the icefield is about $34 \mathrm{~km}^{3}$, which corresponds to an area-average elevation change of $-21 \mathrm{~m}$ (ice equivalent) over the $\sim 43$ year time interval, or a long-term average annual mass balance of $-0.4 \mathrm{~m}$ (water equivalent). Even though these long-term changes are subject to considerable errors associated with the maps (estimated to be about $\pm 5 \mathrm{~m}$ in the area-averaged elevation change), they do provide an important measure of how the different glaciers have been changing, and some idea of the mass of water released by these glaciers into the oceans. This average mass balance is somewhat more negative than that generally found on mountain glaciers elsewhere in the Northern Hemisphere over the past few decades (e.g. Haeberli and others, 1996; Dyurgerov and Meier, 1997). It is also somewhat more negative than that recorded on nearby Wolverine Glacier (USGS, 1997), a record that is often used as an index for this region. It is difficult to determine from the patterns of elevation change alone whether there has been an increase in temperature, or a decrease in precipitation, or both. Inspection of climatological data from the nearby town of Seward for 1908-95 (http://climate.gi.alaska.edu/history/SouthCentral/Seward .html) shows no clear trends, but these data are of questionable quality because the location of the observation site and the time of observation have changed over the period of observation.

The wastage has probably not been uniform in time, as the rate of surface-elevation change between 1994 and 1996 appears to be much larger than the average rate between the 1950 s and the 1990s. However, this short-term value may not be climatically significant, given the annual variation in mass balance of nearby Wolverine Glacier.

There seems to be no significant relation between the type, aspect, size, slope or terminus changes and the volume change. It does appear that a given glacier can be at least qualitatively representative for this region, but it must be carefully chosen. A better approach is to examine changes of several glaciers using surface-elevation profiling.

Our measurements provide an accurate baseline against which future determinations of volume change can be made. New profiles can be flown along the 1994/96 ground tracks and elevation differences calculated using similar techniques.

\section{AGKNOWLEDGEMENTS}

We are grateful to J. Sapiano, B. Rabus, J. Gorda and L. Sombardier for their work on the profiling system and software, and to M. Tetrau for providing the digitized terminus 
positions. We also thank J. Sadlik at the Rocky Mountain Mapping Center for providing the index maps and reports from the time the maps were made. J. G. Cogley, W. Haeberli and C. Lingle provided helpful comments on an earlier version of the manuscript. This work was supported by NASA grant NAGW 3727.

\section{REFERENCES}

Adalgeirsdóttir, G. 1997. Surface elevation and volume changes on the Harding Icefield, southcentral Alaska. (M.Sc. thesis, University of Alaska, Fairbanks.

Benson, C. 1980. Alaska's snow. Weatherwise, 33 (5), 202-205.

Bodvarsson, G. 195.5. On the flow of ice-sheets and glaciers. fökull, 5, $1-8$.

Bredthauer, S. R. and W. D. Harrison. 1984. Impact of glaciers on long-term basin water yield. In Bredthauer, S. R., ed. Alaska's water: a critical resource. Fairbanks, AK, University of Alaska. Institute of Water Resources, 51-59. (Report IWR-106.)

Cohen, S. C. and J. T. Freymueller. 1997. Deformation of the Kenai Peninsula, Alaska. 7. Geophys. Res., 102 (B9), 20,479 20,487.

Dyurgerov, M. B. and M. F. Meier. 1997. Mass balance of mountain and subpolar glaciers: a new global assessment for 1961-1990. Arct. Alp. Res., 29 (4), 379-391.

Echelmeyer, K. A. and 8 others. 1996. Airborne surface profiling of glaciers: a case-study in Alaska. f. Glaciol., 42 142, 538-547.

Hacberli, W. and M. Hoclzle. 1995. Application of inventory data for estimating characteristics of and regional climate-change effects on mountain glaciers: a pilot study in the European Alps. Ann. Glaciol., 21, 206-212.

Haeberli, W., M. Hoelzle and S. Suter. eds. 1996. Glacier Mass Balance Bulletin. Bulletin No. 4 (1994-1995). Zürich, IAHS(ICSI), World Glacier Monitoring Service; Nairobi, UNEP; Paris, UNESCO.

Helm, D. J. and E. B. Allen. 1995. Vegetation chronosequence near Exit Glacier, Kenai Fjords National Park, Alaska, U.S.A. Arct. Alp. Res., 27 3 $3,246-257$.

Holdahl, S. R. and J. Sauber. 1994. Coseismic slip in the 1964 Prince William Sound earthquake: a new geodetic inversion. Pure Appl. Geophys., 142, 55-82.

Jóhannesson, T., C. Raymond and E. D. Waddington. 1989. Time-scale for adjustment of glaciers to changes in mass balance. 7. Glaciol., 35 (121), 355369.

Krimmel, R. M. 1989. Mass balance and volume of South Cascade Glacier, Washington, 1958-1985. In Oerlemans, J., ed. Glacier fluctuations and climatic change. Dordrecht, etc., Kluwer Academic Publishers, 193-206.

Meier, M. F. 1984. Contribution of small glaciers to global sea level. Science,
$226(4681), 1418-1421$

Meier, M. F. 1990. Reduced rise in sea level. Nature, 343 (6254), 115-116.

Meier, M. F. and A. S. Post. 1962. Recent variations in mass net budgets of glaciers in western North America. International Association of Scientific Hydrology Publication 58 (Symposium at Obergurgl 1962 - Variations of the Regime of Existing Glaciers ), 63-77.

Mercer, J. H. 1961. The response of fjord glaciers to changes in the firn limit. 7. Glaciol., 3 (29), 850-858.

Oerlemans, J. 1994. Quantifying global warming from the retreat of glaciers. Science, 264 (5156), 243-245.

Post, A. 1980a. Preliminary bathymetry of Aialik Bay and neoglacial changes of Aialik and Pederson Glaciers, Alaska. U.S. Geol. Surv. Open File Rep. 80-423.

Post, A. 1980b. Preliminary bathymetry of McCarty Fiord and neoglacial changes of McCarty Glacier, Alaska. U.S. Geol. Surv. Open File Rep. 80-424.

Post, A. 1980c. Preliminary bathymetry of Northwestern Fiord and neoglacial changes of Northwestern Glacier, Alaska. U.S. Geol. Surv. Open File Rep. 80-414.

Rabus, B.T. and K. A. Echelmeyer. In press. The mass balance of McCall Glacier, Brooks Range, Alaska: its regional relevance and implications for the climate change in the Arctic. F. Glaciol.

Rabus, B., K. Echelmeyer, D. Trabant and C. Benson. 1995. Recent changes of McCall Glacier, Alaska. Ann. Glaciol., 21, 231-239.

Rice, B. 1987. Changes in the Harding Icefield, Kenai Peninsula, Alaska: with management implications for Kenai Fjords National Park. (M.Sc. thesis, University of Alaska. School of Agriculture and Land Resources.

Sapiano, J. J., W. D. Harrison and K. A. Echelmeyer. 1998. Elevation, volume and terminus changes of nine glaciers in North America. 7. Glaciol., 44(146), 119-135.

United States Geological Survey (USGS). 1990. Digital elevation models: data users guide 5. Reston, VA, U.S. Geological Survey.

United States Geological Survey (USGS). 1997. Benchmark glaciers, Reston, VA, U.S. Geological Survey. (http://orcapaktcm.wr.usgs.gov.

Viens, R. J. 1995. Dynamics and mass balance of temperate tidewater calving glaciers of southern Alaska. (M.Sc. thesis, University of Washington.

Wiles, G. C. and P. E. Calkin. 1990. Neoglaciation in the southern Kenai Mountains, Alaska. Ann. Glaciol., 14, 319-322.

Wiles, G. C. and P. E. Calkin. 1994. Late Holocene, high-resolution glacial chronologies and climate, Kenai Mountains, Alaska. Geol. Soc. Am. Bull. $106(2), 281-303$

Wiles, G. C., P. E. Calkin and A. Post. 1995. Glacier fluctuations in the Kenai Fjords, Alaska, U.S.A.: an evaluation of controls on iceberg-calving glaciers. Arct. Alp. Res., 27 (3), 234-245. 